\title{
How much asthma is really attributable to atopy?
}

\author{
Neil Pearce, Juha Pekkanen, Richard Beasley
}

In recent decades it has become routine to describe asthma as an atopic disease. A theoretical paradigm has evolved in which allergen exposure produces atopic sensitisation and continued exposure leads to clinical asthma through the development of airways inflammation, bronchial hyperresponsiveness, and reversible airflow obstruction. As Martinez ${ }^{1}$ notes, this paradigm has been used with particular insistence with regard to house dust mite allergens, ${ }^{23}$ but other allergens (cat, cockroach, dog) are also believed to be important. The importance of atopy is most widely accepted for asthma in children whereas, among adults, asthma has traditionally been divided into "extrinsic" and "intrinsic" asthma, although this also has been challenged. ${ }^{4}$ It is acknowledged that not all cases of asthma fit this paradigm - for example, some occupational causes of asthma do not appear to involve atopy - but these are regarded as interesting minor anomalies that do not threaten the dominant paradigm.

In this review we assess the extent to which the development of asthma is attributable to atopy (we do not consider the separate issue of the extent to which the development of atopy itself is attributable to allergen exposure, although this is also the subject of debate ${ }^{1}$ ). We start by considering definitions of asthma and atopy and then review evidence on their association in random population surveys. We do not intend to argue that atopy does not play an important role in the development of a significant proportion of asthma cases. However, our concern is that the proportion of asthma cases attributable to atopy may have been overestimated, and that other possible aetiological mechanisms and risk factors for asthma may therefore have been neglected.

\section{Definitions of asthma and atopy}

The definition of asthma is still controversial but an appropriate definition is a precondition for addressing the issues considered in this paper. The term "asthma" encompasses a disparate group of disorders which produce similar clinical effects - that is, variable airflow obstruction ${ }^{5}$ - and this has formed the basis of the definition of asthma. ${ }^{67}$ Some current definitions also emphasise the importance of airways inflammation, ${ }^{8}$ although the relationship between airways inflammation and variable airways obstruction is not straightforward. ${ }^{9-12}$ In some studies asthma has been defined more restrictively in terms of the immunological or pathophysiological mechanisms by which variable airflow obstruction is presumed to have occurred-for example, atopy or bronchial hyperresponsiveness (BHR). However, this leads to a significant proportion of asthma cases being excluded, and the relationship between "asthma" and atopy or BHR then becomes merely tautological. Thus, asthma is best defined in terms of the phenomena involved - that is, variable airflow obstruction-without making any restrictions based on possible aetiological considerations. ${ }^{1314}$ For these reasons we have focused on studies that used physician diagnoses of asthma or self-reported asthma or asthma symptoms. We did not use definitions of asthma based on BHR since this would also lead to a considerable proportion of asthma cases being excluded, ${ }^{15}$ and because BHR is part of the causal model that we are assessing (in fact, atopy is more strongly associated with BHR than it is with airflow variability ${ }^{16}$ ).

"Atopy" has previously been used as a poorly defined term to refer to allergic conditions which tend to cluster in families, including hay fever (allergic rhinitis), asthma, eczema, and other specific and non-specific allergic states. ${ }^{17}$ More recently, atopy has been characterised by the production of specific IgE in response to common environmental allergens, ${ }^{18}$ and skin prick testing provides a convenient test for atopy in epidemiological studies. ${ }^{19}$ However, it has been suggested that total serum IgE provides an overall estimate of the allergic component in asthma, ${ }^{4}$ and that total serum $\operatorname{IgE}$ is associated with asthma independently of specific IgE levels. ${ }^{20}$ In this review we therefore focus on studies of skin prick test positivity, but we also consider studies of total serum $\operatorname{IgE}$ levels.

To assess the association of atopy with asthma in individuals and in populations we conducted a Medline search from 1980 onwards for English language publications of studies that contained at least one of the key words "hypersensitivity, immediate", "hypersensitivity", "IgE", or "skin tests". From these we selected epidemiological studies on asthma ("asthma" combined with "cross-sectional studies", "case-control studies", "longitudinal studies" or "prevalence"; or "respiratory tract disease/epidemiology"; or "asthma/epidemiology"; or "bronchitis/epidemiology"). We then selected only population based studies with a source population of at least 600 subjects (in some instances these were prevalence casecontrol studies and the total number of cases and controls was less than 600 , even though the source population was larger than 600 ). For the reasons noted above we excluded studies that used BHR in their definition of asthma. We also excluded studies which did not report the proportions with atopy or with raised total serum IgE levels among cases and non-cases, and studies using IgE levels measured before the age of one year. For studies with multiple publications we only used one report. 
Table 1 Percentage of asthma cases attributable to atopy (defined as at least one positive skin prick test) in population based studies

\begin{tabular}{|c|c|c|c|c|c|c|c|c|}
\hline \multirow[b]{2}{*}{ Reference } & \multirow[b]{2}{*}{ Age } & \multicolumn{2}{|c|}{ Non-asthmatics } & \multicolumn{2}{|c|}{ Asthmatics } & \multirow[b]{2}{*}{$\begin{array}{l}\text { Relative } \\
\text { risk }\end{array}$} & \multirow{2}{*}{$\begin{array}{l}\% \text { of cases } \\
\text { attributable } \\
\text { to atopy }\end{array}$} & \multirow[b]{2}{*}{ Definition of asthma } \\
\hline & & No. & $\begin{array}{l}\text { Atopy } \\
(\%)\end{array}$ & No. & $\begin{array}{l}\text { Atopy } \\
(\%)\end{array}$ & & & \\
\hline \multicolumn{9}{|c|}{ Studies exclusively or predominantly in children } \\
\hline Gergen et $a l^{1}$ & $6-17$ & 5505 & 21 & 395 & 45 & 3.1 & 30 & Diagnosis or frequent wheezing \\
\hline Burrows et $a l^{4}$ & $6-34$ & 994 & 44 & 89 & 79 & 4.8 & 63 & "Asthma" + symptoms \\
\hline Sears $e t a l^{22}$ & 13 & 399 & 35 & 315 & 57 & 2.5 & 34 & Clinical examination \\
\hline Norrman et al $l^{3}$ & 14 & 887 & $40^{\star}$ & 110 & 66 & 2.5 & 40 & Ever asthma \\
\hline \multirow[t]{2}{*}{ Von Mutius et al $l^{4}$} & $9-11 \dagger$ & 4756 & 37 & 274 & 69 & 3.8 & 51 & Diagnosis with current symptoms \\
\hline & $9-12 \ddagger$ & 2523 & 18 & 100 & 40 & 3.0 & 27 & Diagnosis with current symptoms \\
\hline Martinez et al $2^{5}$ & 6 & 442 & 35 & 187 & 56 & 2.3 & 32 & Persistent or late onset wheeze \\
\hline Brooke et $a l^{6}$ & $4-9$ & 220 & 26 & 54 & 54 & 3.3 & 38 & Current wheeze \\
\hline Sporik et $a l^{7}$ & $12-14$ & 53 & 64 & 67 & 73 & 1.5 & 25 & Respiratory symptoms \\
\hline Remes and Korppi ${ }^{28}$ & $7-12$ & 204 & 46 & 43 & 77 & 3.8 & 57 & Clinical examination \\
\hline \multicolumn{9}{|c|}{ Studies exclusively or predominantly in adults } \\
\hline \multirow[t]{2}{*}{ Burrows $e t a l^{4}$} & $35-54$ & 498 & 40 & 47 & 72 & 3.9 & 53 & Asthma with symptoms \\
\hline & $55+$ & 928 & 23 & 101 & 40 & 2.2 & 22 & Asthma with symptoms \\
\hline Mensinga $e t a l^{9} \mathbb{S}$ & $17-49$ & 2711 & 26 & 94 & 46 & 2.4 & 27 & Asthma attacks ever \\
\hline Sparrow et $a l^{30}$ & $41-86$ & 598 & 23 & 28 & 29 & 1.4 & 8 & Adult onset wheeze \\
\hline Wüthrich et $a l^{31}$ & $18-60$ & 7789 & $21^{\star}$ & 568 & 56 & 4.8 & 44 & Diagnoses \\
\hline Settipane $e t a l^{32}$ & $40-42$ & 654 & 35 & 36 & 56 & 2.4 & 32 & Asthma attacks \\
\hline Bodner $e t a l^{33}$ & $39-45$ & 217 & 45 & 102 & 55 & 1.5 & 18 & Adult onset wheeze \\
\hline Siracusa et $a l^{34}$ & $0-69$ & 783 & 19 & 41 & 63 & 7.3 & 55 & Current diagnosed asthma \\
\hline
\end{tabular}

^Estimated.

+West Germany.

‡East Germany.

SAtopy definition based on skin prick index (no. of positive reactions $\times$ size of weals).

Trospective study, age at end of follow up.

All studies are based on a source population of at least 600 subjects but some prevalence case-control studies involve smaller numbers of cases and controls.

\section{Association of atopy with asthma in individuals}

The proportion of asthma cases that are "attributable" to atopy (defined as skin prick test positivity) can be estimated by the "population attributable risk". If exposure has an odds ratio for asthma of $\mathrm{R}$ (the odds ratio is the appropriate measure to use in prevalence studies and prevalence case-control studies ${ }^{15}$ ), then the proportion of exposed cases that are attributable to exposure is $(\mathrm{R}-1) / \mathrm{R}$, and the proportion of all cases in the population that are attributable to exposure (population attributable risk) is $\mathrm{P}(\mathrm{R}-1) / \mathrm{R}$ where $\mathrm{P}$ is the proportion of all cases that are exposed.

\section{SKIN PRICK TEST POSITIVITY}

The proportions of asthmatic and nonasthmatic subjects who are skin prick test posi-

Table 2 Percentage of asthma cases attributable to atopy based on number of positive skin prick tests and specific skin prick tests

\begin{tabular}{lcccc}
\hline Skin prick tests * & $\begin{array}{l}\text { \% Non asthmatics } \\
\text { atopic }(n=399)\end{array}$ & $\begin{array}{l}\text { \% Asthmatics } \\
\text { atopic }(n=315)\end{array}$ & $\begin{array}{l}\text { \%elative risk } \\
\text { attributable to atopy }\end{array}$ \\
\hline No. of positive tests & & & & \\
$1+$ & 35.1 & 57.1 & 2.5 & 34 \\
$2+$ & 16.5 & 40.6 & 3.5 & 29 \\
$3+$ & 7.3 & 27.3 & 4.8 & 22 \\
$4+$ & 2.0 & 14.3 & 8.1 & 13 \\
$5+$ & 1.0 & 9.8 & 10.8 & 9 \\
$6+$ & 0.5 & 7.0 & 14.9 & 7 \\
$7+$ & 0.3 & 2.9 & 11.7 & 3 \\
Specific skin prick tests & & & & \\
Any positive test & 35.1 & 57.1 & 2.5 & 34 \\
Rye grass & 23.4 & 44.4 & 2.6 & 27 \\
House dust mite & 19.4 & 43.7 & 3.2 & 30 \\
Cat & 5.5 & 23.2 & 5.2 & 19 \\
Alternaria & 4.5 & 8.6 & 2.0 & 4 \\
Dog & 2.2 & 9.9 & 4.9 & 8 \\
Horse & 1.8 & 10.2 & 6.3 & 9 \\
Cladosporium & 1.3 & 5.7 & 4.7 & 4 \\
Kapok & 1.5 & 4.1 & 2.8 & 3 \\
Aspergillus fumigatus & 0.5 & 4.8 & 9.7 & 4 \\
Wool & 0.8 & 4.4 & 6.0 & 4 \\
Penicillium & 2.0 & 2.5 & 1.3 & 1 \\
\hline
\end{tabular}

${ }^{\star}$ Defined as the development of weals at least $2 \mathrm{~mm}$ greater than negative control. Adapted from Sears et al..$^{22}$ tive vary considerably between different studies $^{421-34}$ (table 1). The weighted mean of the estimates from these studies, mostly conducted in Western countries, indicates that overall about $58 \%$ of children and $54 \%$ of adults with asthma were skin prick test positive; however, about $29 \%$ of non-asthmatic children and $24 \%$ of non-asthmatic adults were also skin prick test positive. The proportion of cases attributable to atopy varied from $25 \%$ to $63 \%$ in cross-sectional studies exclusively or predominantly in children, with a weighted mean of about $38 \%$; in studies exclusively or predominantly in adults, the population attributable risk varied from $8 \%$ to $55 \%$ with a weighted mean of $37 \%$. Thus, the population attributable risk was similar in children and adults, but it should be emphasised that these studies were not all done in the same populations and, in fact, studies performed within a single population (for example, reference 4) found higher attributable risks in children than in adults.

It might be argued that the definition of skin prick test positivity used in these studies is too weak or non-specific since it is based on "at least one positive skin test" from a range of allergens. We therefore considered data from Sears et $a l^{2}$ because this publication included the necessary information and the population attributable risk of atopy for asthma in this study $(34 \%)$ was similar to the average for all studies in children in table $1(38 \%)$. Table 2 shows that, as the definition of atopy (in terms of the number of positive skin prick test responses) is strengthened, the association with asthma also strengthens - that is, the odds ratio increases - but the population attributable risk decreases from $34 \%$ to $3 \%$ because of the reduction in the proportion of the population that is "positive". Thus, when a more "severe" 
Table 3 Percentage of asthma cases attributable to atopy (defined as a total serum IgE level of 100+ IU/ml) in population based studies

\begin{tabular}{|c|c|c|c|c|c|c|c|c|}
\hline \multirow[b]{2}{*}{ Reference } & \multirow[b]{2}{*}{ Age } & \multicolumn{2}{|c|}{ Non-asthmatics } & \multicolumn{2}{|c|}{ Asthmatics } & \multirow[b]{2}{*}{$\begin{array}{l}\text { Relative } \\
\text { risk }\end{array}$} & \multirow{2}{*}{$\begin{array}{l}\% \text { of cases } \\
\text { attributable to } \\
\text { atopy }\end{array}$} & \multirow[b]{2}{*}{ Definition of asthma } \\
\hline & & No. & $\begin{array}{l}\text { Atopy } \\
(\%)\end{array}$ & No. & $\begin{array}{l}\text { Atopy } \\
(\%)\end{array}$ & & & \\
\hline \multirow[t]{3}{*}{ Burrows et $a l^{4}$} & $6-34$ & 994 & 30 & 89 & 73 & 6.3 & 61 & "Asthma" + symptoms \\
\hline & $35-54$ & 498 & 18 & 47 & 57 & 6.0 & 48 & "Asthma" + symptoms \\
\hline & $55+$ & 928 & 13 & 101 & 34 & 3.5 & 24 & "Asthma" + symptoms \\
\hline Remes and Korppi ${ }^{28}$ & $7-12$ & 204 & 45 & 43 & 38 & 0.7 & -16 & Clinical examination \\
\hline Sears $e t a l^{35}$ & 11 & 500 & 46 & 62 & 89 & 9.5 & 80 & Diagnosed current asthma \\
\hline Burrows et $a l^{3 \star \star}$ & $15+$ & 2255 & 12 & 160 & 38 & 4.5 & 30 & Current diagnosed asthma \\
\hline Sunyer $e t a l^{20}$ & $20-44$ & 1761 & 25 & 155 & 50 & 3.0 & 33 & Asthma attack ever \\
\hline Bodner $e t a b^{33}$ & $39-45$ & 217 & 13 & 102 & 23 & 2.0 & 11 & Adult onset wheeze \\
\hline
\end{tabular}

*Atopy defined as a total serum IgE level of $160+\mathrm{IU} / \mathrm{ml}$.

definition of atopy is used-for example, four or more positive skin prick tests-the association with asthma (as reflected in the relative risk estimate) increases, but the proportion of cases that are atopic (according to the more severe definition) decreases and the population attributable risk decreases. Similar analyses for the allergen-specific test results (table 2) showed that some specific allergens had stronger associations with asthma, but that the highest estimate of the population attributable risk $(34 \%)$ is obtained with "any positive skin test".

SERUM IgE

An obvious limitation of these data is that skin prick testing uses a wide range of allergens believed to be predominant in the area under study, but it will not necessarily identify all cases of atopy. It is therefore important also to consider atopy as defined in terms of total serum IgE, since it has been suggested that it provides an overall estimate of the allergic component in asthma ${ }^{4}$ and because it is more readily comparable between studies. Table 3 summarises the studies of total serum $\mathrm{IgE}^{4028333536}$ and shows that the population attributable risk of atopy (defined as a raised total serum IgE level) for asthma varied from less than $0 \%$ (an inverse association) to $80 \%$ with a weighted mean of $33 \%$.

Once again, these findings depend on the cut off point that is used to define atopy, and Burrows et $a l^{4}$ have argued that some type of $\operatorname{IgE}$ mediated process may be involved in almost all asthma cases, even when skin test reactivity to common allergens is not found. Thus, if a more liberal definition of atopy (in terms of raised serum IgE levels) is used, a higher proportion of asthmatic subjects might be considered to be atopic. Table 4 shows data from Burrows et $a l^{36}$ with the attributable risk estimates that would be obtained using different cut off points for

Table 4 Percentage of asthma cases attributable to atopy, using different cut off levels for total serum IgE

\begin{tabular}{lllll}
\hline $\begin{array}{l}\text { Serum IgE level } \\
\text { IUU/ml) }\end{array}$ & $\begin{array}{l}\text { \% Non asthmatics } \\
\text { atopic }(n=2255)\end{array}$ & $\begin{array}{l}\text { \% Asthmatics } \\
\text { atopic }(n=160)\end{array}$ & Relative risk & $\begin{array}{l}\text { \% of cases } \\
\text { attributable to atopy }\end{array}$ \\
\hline $640+$ & 3.5 & 15.6 & 5.2 & 13 \\
$320+$ & 7.0 & 26.9 & 4.9 & 21 \\
$160+$ & 11.7 & 38.1 & 4.6 & 30 \\
$80+$ & 25.0 & 56.3 & 3.9 & 42 \\
$40+$ & 41.4 & 71.3 & 3.5 & 51 \\
$20+$ & 57.1 & 81.3 & 3.3 & 56 \\
$10+$ & 72.4 & 90.0 & 3.4 & 64 \\
$5+$ & 84.8 & 95.0 & 3.4 & 67 \\
\hline
\end{tabular}

Adapted from Burrows et al. ${ }^{36}$ serum IgE. Once again this study was chosen because it reported the relevant information, and because the population attributable risk of atopy for asthma in this study (30\%) was similar to the weighted average for all studies $(33 \%)$. The proportion of cases attributable to atopy continues to increase as the definition of atopy is "loosened" but, even using the most liberal definition (in which $85 \%$ of nonasthmatic patients and $95 \%$ of asthmatic patients are considered to be atopic), only about two thirds of the asthma cases are attributable to atopy.

These findings are likely to be underestimates because non-differential misclassification of atopy and/or asthma will usually bias the relative risk estimate towards the null value. ${ }^{15}$ On the other hand, the association between total serum IgE and asthma may in part, at least in some cases, simply be an association rather than reflecting a causal link. In particular, Sunyer et $a l^{20}$ have suggested that: coinherited genetic factors could increase susceptibility both to asthma and to the production of raised serum IgE levels; total serum IgE levels could in part be a consequence of asthma itself and could be a marker of non-allergic inflammation; or that IgE could also express a humoral autoimmunity since specific reactivity against human proteins structurally similar to allergens has been described. In each of these situations the association between total serum $\operatorname{IgE}$ and asthma would not be entirely causal, and the findings presented here would therefore be overestimates.

\section{Association of atopy with asthma in populations}

It is also of interest to consider the associations of the atopy measures with asthma prevalence at the population level, particularly in light of the global increases ${ }^{37}$ and the substantial international differences ${ }^{38} 39$ in the prevalence of asthma.

Table 5 summarises studies, identified from the same Medline search used for table 1, in which asthma and atopy (skin prick test positivity) were measured in the same population at different times, or in two or more different populations at the same time. Although a few studies suggest an association between the prevalence of atopy and asthma (Charpin et $a l^{40}$ Wieringa et $a l^{45}$ ), most studies do not. For example, Peat et $a l^{42}$ found little or no association between the prevalence of atopy 
Table 5 Prevalence of skin prick test positivity and asthma in population based studies comparing different populations or the same population over time

\begin{tabular}{|c|c|c|c|c|c|}
\hline Reference & Population & No. & Age & $\begin{array}{l}\% \text { with +ve skin } \\
\text { prick test }\end{array}$ & $\begin{array}{l}\% \text { with doctor diagnosed } \\
\text { asthma or 'asthma' }\end{array}$ \\
\hline \multicolumn{6}{|c|}{ Comparisons of populations } \\
\hline \multirow[t]{2}{*}{ Charpin $e t a l^{40}$} & Marseille & 4008 & $18-65$ & $28^{\star}$ & 4 \\
\hline & Briancon & 1055 & $18-65$ & $10^{\star}$ & 2 \\
\hline \multirow{2}{*}{ Von Mutius ${ }^{24}$} & Munich & 4451 & $9-11$ & 37 & 9 \\
\hline & Leipzig/Halle & 2335 & $9-11$ & 18 & 7 \\
\hline \multirow[t]{3}{*}{ Leung and $\mathrm{Ho}^{41}$} & Malaysia & 321 & 16 & 64 & 3 \\
\hline & Hong kong & 471 & 14 & 58 & 7 \\
\hline & China & 647 & 16 & 49 & 2 \\
\hline \multirow[t]{7}{*}{ Peat $e t a l^{42}$} & Sydney & 1339 & $8-11$ & 42 & 24 \\
\hline & West Sydney & 904 & $8-11$ & 42 & 28 \\
\hline & Moree/Narrabi & 770 & $8-11$ & 40 & 31 \\
\hline & Wagga Wagga & 850 & $8-11$ & 40 & 29 \\
\hline & Belmont & 926 & $8-11$ & 39 & 38 \\
\hline & Broken Hill & 794 & $8-11$ & 37 & 30 \\
\hline & Lismore & 805 & $8-11$ & 35 & 31 \\
\hline \multirow[t]{2}{*}{ Nowack et $a l^{43}$} & Hamburg & 1159 & $20-44$ & 36 & 2 \\
\hline & Erfurt & 731 & $20-44$ & 30 & 1 \\
\hline \multirow[t]{2}{*}{ Yemaneberhan $^{44}$} & Rural Ethiopia & 861 & $5-70+$ & $12^{\star}$ & 1 \\
\hline & Urban Ethiopia & 2194 & $5-70+$ & $4^{\star}$ & 4 \\
\hline \multirow[t]{2}{*}{ Wieringa et $a l^{45}$} & Urban Antwerp & 319 & $20-44$ & $26^{\star}$ & 7 \\
\hline & Suburban Antwerp & 337 & $20-44$ & $17^{\star}$ & 4 \\
\hline \multicolumn{6}{|c|}{ Comparisons of time periods } \\
\hline \multirow[t]{2}{*}{ Peat et $a l^{46}$} & Busselton 1981 & 553 & $18-55$ & 39 & 9 \\
\hline & Busselton 1990 & 1028 & $18-55$ & 41 & 16 \\
\hline \multirow[t]{4}{*}{ Peat $e t a l^{47}$} & Belmont 1982 & 718 & $8-10$ & 28 & 9 \\
\hline & Belmont 1992 & 873 & $8-10$ & 29 & 38 \\
\hline & Wagga Wagga 1982 & 769 & $8-10$ & 30 & 13 \\
\hline & Wagga Wagga 1992 & 795 & $8-10$ & 35 & 30 \\
\hline \multirow[t]{2}{*}{ Von Mutius $e t a l^{48}$} & Leipzig/Halle 1991/2 & 1492 & $9-11$ & 19 & 4 \\
\hline & Leipzig/Halle 1995/6 & 2311 & $9-11$ & 27 & 4 \\
\hline
\end{tabular}

*Skin prick positivity to house dust mites.

and diagnosed asthma in different parts of Australia.

Similarly, Leung and $\mathrm{Ho}^{41}$ reported that asthma prevalence was high in Hong Kong ( $7 \%$ for asthma ever), intermediate in Malaysia $(3 \%)$, and low in San $\mathrm{Bu}$, China (2\%), but atopy prevalence was similar in the three centres $(58 \%, 64 \%$ and $49 \%$, respectively).

Yemaneberhan et $a l^{44}$ reported major differences in the prevalence of asthma between rural $(1 \%)$ and urban (4\%) populations in southwest Ethiopia. However, skin prick test positivity to house dust mites was more common in rural $(12 \%)$ than in the urban $(4 \%)$ areas; there was little difference in the prevalence of skin prick positivity to other allergens such as mixed threshings or Aspergillus (not shown in table).

There is evidence of an association of the prevalence of atopy with the prevalence of asthma in the studies showing higher levels of both in Western than in Eastern Europe. ${ }^{24}$ However, no increase in the prevalence of asthma was observed among East German children between 1991 and 1996, although the prevalence of atopy increased from 19\% to $27 \%{ }^{48}$ On the other hand, Peat et $a l^{46}{ }^{47}$ found marked increases in diagnosed asthma in Busselton, Belmont, and Wagga Wagga, Australia (there were similar but less dramatic increases in the 12 month period prevalences of wheezing, not shown in table), but there was little change in the prevalence of atopy in these three centres (table 5).

The European Community Respiratory Health Survey ${ }^{49}$ has not yet fully published its results, but the prevalence of atopy (defined as raised specific serum IgE levels) appears to be associated with the prevalence of subjects reporting asthma attacks ${ }^{38}$ at the country level. However, this association is mainly driven by the English speaking countries with other European countries showing only a weak association, and no association has been observed between the prevalence of asthma and total serum IgE levels. ${ }^{49}$

\section{Conclusions}

The available epidemiological evidence suggests that the population based proportion of asthma cases that are attributable to atopy is usually less than one half. Higher estimates (up to two thirds) can be obtained by using very low cut off levels of total serum IgE, but these should be interpreted with caution since such a definition of atopy has limited practical use, and these associations may not always be causal. Moreover, standardised comparisons across populations or time periods show only a weak and inconsistent association between the prevalence of asthma and the prevalence of atopy. These findings indicate that the importance of atopy as a cause of asthma in individuals may have been overemphasised. The danger is that overemphasis on a particular theoretical paradigm for which the evidence is less substantial than is commonly assumed may have led to an under-recognition of, and insufficient research into, other possible aetiological mechanisms for the development of asthma.

The Wellington Asthma Research Group is supported by a Programme Grant from the Health Research Council of New Zealand and by a major grant from the Guardian Trust (Trustee of the David and Cassie Anderson Medical Charitable Trust). Juha Pekkanen was supported by the Academy of Finland.

\footnotetext{
1 Martinez FD. Complexities of the genetics of asthma. Am $\mathcal{F}$ Respir Crit Care Med 1997;156:S117-22.

2 Peat JK, Tovey E, Toelle BG, et al. House dust mite allergens: a major risk factor for childhood asthma in Aus-
tralia. Am f Respir Crit Care Med 1996;153:141-6.
} 
3 Platts-Mills TAE, Sporik RB, Chapman MD, et al. The role of domestic allergens. In: The rising trends in asthma. Ciba Foundation Symposium 206. Chichester: Wiley, 1997: 173-89.

4 Burrows B, Martinez FD, Halonen M, et al. Association of asthma with serum IgE levels and skin-test reactivity to allergens. N Engl f Med 1989;320:271-7.

5 Barnes PJ, Djukanovic R, Holgate ST. Pathogenesis. In Brewis RAL, Corrin B, Geddes DM, Gibson GJ, eds. Res piratory medicine. 2nd ed. London: WB Saunders, 1995: 1108-53.

6 Ciba Foundation Guest Symposium. Terminology definitions, classification of chronic pulmonary emphysema and related conditions. Thorax 1959;14:286-99.

7 American Thoracic Society Committee on Diagnostic Standards. Definitions and classification of chronic bronchitis, asthma and pulmonary emphysema. Am Rev Respir Dis 1962;85:762-8.

8 NHLBI. International consensus report on diagnosis and treatment of asthma. National Health, Lung and Blood treatment of asthma. National Health,
Institute. Washington, DC: DHHS, 1992.

9 Hogg C, Bush A. Childhood asthma: all that wheezes is not Hogg C, Bush A. Childhood asthma: all that wh

10 Stevenson EC, Turner G, Heaney LG, et al. Bronchoalveolar lavage findings suggest two different forms of childhood asthma. Clin Exp Allergy 1997;27:1027-35.

11 Haley KJ, Drazen JM. Inflammation and airway function in asthma: what you see is not necessarily what you get. $A m \mathcal{F}$ Respir Crit Care Med 1998;157:1-3.

12 Crimi E, Spanevello A, Neri M, et al. Dissociation between airway inflammation and airway hyperresponsiveness in allergic asthma. Am 7 Respir Crit Care Med 1998;157:4-9.

13 Gregg I. Epidemiological aspects. In: Clark TJK, Godfrey S, eds. Asthma. London: Chapman \& Hall, 1983:242-84.

14 Gross NJ. What is this thing called love? or, defining asthma. Am Rev Respir Dis 1980;121:203-4.

15 Pearce N, Beasley R, Burgess C, et al. Asthma epidemiology: principles and methods. New York: Oxford University Press, principles 1998 .

16 Stein RT, Holberg C, Morgan WJ, et al. Peak flow variability, methacholine responsiveness and atopy as markers for detecting different whe
Thorax 1997;52:946-52.

17 Burney PGJ, Anderson HR, Burrows B, et al. Epidemiology. In: Holgate ST, Howell JBL, Burney PGJ, et al, eds. The role of inflammatory processes in airway hyperresponsiveness. Oxford: Blackwell Scientific, 1989:222-50.

18 Jarvis D, Burney P. The epidemiology of allergic disease. BMF 1998;316:607-10

19 Oryszczyn M-P, Annesi I, Neukirch F, et al. Relationships of total IgE level, skin prick test response, and smoking habits. Ann Allergy 1991;67:355-9.

20 Sunyer J, Antó JM, Castellsagué J, et al. Total serum IgE is associated with asthma independently of specific IgE levels. Eur Respir f 1996;9:1880-4.

21 Gergen PJ, Mullally DI, Evans III R. National survey of prevalence of asthma among children in the United States, prevalence of asthma among children
1976 to 1980 . Pediatrics $1988 ; 81: 1-7$.

22 Sears MR, Herbison GP, Holdaway MD, et al. The relative risks of sensitivity to grass pollen, house dust mite and cat dander in the development of childhood asthma. Clin Exp Allergy 1989;19:419-24.

23 Norrman E, Rosenhall L, Nyström L, et al. Prevalence of positive skin prick tests, allergic asthma, and rhinoconjunctivitis in teenagers in northern Sweden. Allergy 1994;49: 808-15.

24 Von Mutius E, Martinez FD, Fritzsch C, et al. Prevalence of asthma and atopy in two areas of West and East Germany. Am f Respir Crit Care Med 1994;149:358-64.

25 Martinez FD, Wright AL, Taussig LM, et al. Asthma and wheezing in the first six years of life. $N$ Engl $f \mathrm{Med}$ 1995;332:133-82.

26 Brooke AM, Lambert PC, Burton PR, et al. The natural history of respiratory symptoms in preschool children. $A m \mathcal{F}$ Respir Crit Care Med 1995;152:1872-8.

27 Sporik R, Ingram JM, Price W, et al. Association of asthma with serum IgE and skin test reactivity to allergens among children living at high altitude: tickling the dragon's breath Am F Respir Crit Care Med 1995;151:1388-92.
28 Remes ST, Korppi M. Asthma and atopy in schoolchildren in a defined population. Acta Paediatr 1996;85:965-70.

29 Mensinga TT, Schouten JP, Rijcken B, et al. The relationship of eosinophilia and positive skin test reactivity to respiratory symptom prevalence in a community-based population study. F Allergy Clin Immunol 1990;86:99-107.

30 Sparrow D, O'Connor GT, Basner C, et al. Predictors of the new onset of wheezing among middle-aged and older men. Am Rev Respir Dis 1993;147:367-71.

31 Wüthrich B, Schindler C, Leuenberger P, AckermannLiebrich $U$ and the SAPALDIA team. Prevalence of atopy and pollinosis in the adult population of Switzerland (SAPALDIA study). Int Arch Allergy Immunol 1995;106: 149-56.

32 Settipane RJ, Hagy GW, Settipane GA. Long-term risk factors for developing asthma and allergic rhinitis: a 23-year follow-up study of college students. Allergy Proc 1994;15: 21-5.

33 Bodner CH, Ross S, Little J, et al. Risk factors for adult onset wheeze: a case control study. Am $\mathcal{f}$ Respir Crit Care Med 1998:157:35-42.

34 Siracusa A, Marabini A, Sensi L, et al. Prevalence of asthma and rhinitis in Perugia, Italy. Monaldi Arch Chest Dis 1997; 52:434-9.

35 Sears MR, Burrows B, Flannery EM, et al. Relation between airway responsiveness and serum $\mathrm{IgE}$ in children with asthma and in apparently normal children. $N$ Engl f Med 1991;325:1067-71.

36 Burrows B, Halonen M, Lebowitz MD, et al. The relationship of serum immunoglobulin $\mathrm{E}$, allergy skin tests, and smoking to respiratory disorders. F Allergy Clin Immunol 1982;70:199-204.

37 Global Initiative for Asthma (GINA). Global strategy for asthma management and prevention. NHLBI/WHO Workshop Report. Washington, DC: NIH, 1995.

38 European Community Respiratory Health Survey (ECRHS). Variations in the prevalence of respiratory symptoms, self reported asthma attacks, and use of asthma medication in the European Community Respiratory Health Survey (ECRHS). Eur Respir f 1996;9:687-95.

39 ISAAC Steering Committee. Worldwide variation in prevalence of symptoms of asthma, allergic rhinoconjunctivitis lence of symptoms of asthma, allergic rhinoconjunctivit

40 Charpin D, Kleisbauer J-P, Lanteaume A, et al. Asthma and allergy to house-dust mites in populations living in high altitudes. Chest 1988;93:758-61.

41 Leung R, Ho P. Asthma, allergy, and atopy in three south-east Asian populations. Thorax 1994;49:1205-10.

42 Peat JK, Toelle BG, Gray EJ, et al. Prevalence and severity of childhood asthma and allergic sensitisation in seven climatic regions of New South Wales. Med f Aust 1995;163:22-6.

43 Nowak D, Heinrich J, Jörres R, et al. Prevalence of respiratory symptoms, bronchial hyperresponsiveness and atopy among adults: West and East Germany. Eur Respir $\mathcal{F} 1996$; 9:2541-52.

44 Yemaneberhan H, Bekele Z, Venn A, et al. Prevalence of wheeze and asthma and relation to atopy in urban and rural Ethiopia. Lancet 1997;350:85-90.

45 Wieringa $\mathrm{MH}$, Weyler JJ, Van Bastelaer FJ, et al. Higher asthma occurrence in an urban than a suburban area: role of house dust mite skin allergy. Eur Respir F 1997;10:14606.

46 Peat JK, Haby M, Spijker J, et al. Prevalence of asthma in adults in Busselton, Western Australia. BMF 1992;305: $1326-9$.

47 Peat JK, van den Berg RH, Green WF, et al. Changing prevalence of asthma in Australian children. BMF 1994; 308:1591-6.

48 Von Mutius E, Weiland SK, Fritzsch C, et al. Increasing prevalence of hay fever and atopy among children in Leipzig, East Germany. Lancet 1998;351:862-6.

49 Burney P, Malmberg E, Chinn S, et al. The distribution of total and specific serum IgE in the European Community Respiratory Health Survey. $\mathcal{F}$ Allergy Clin Immunol 1997;99: 314-22. 